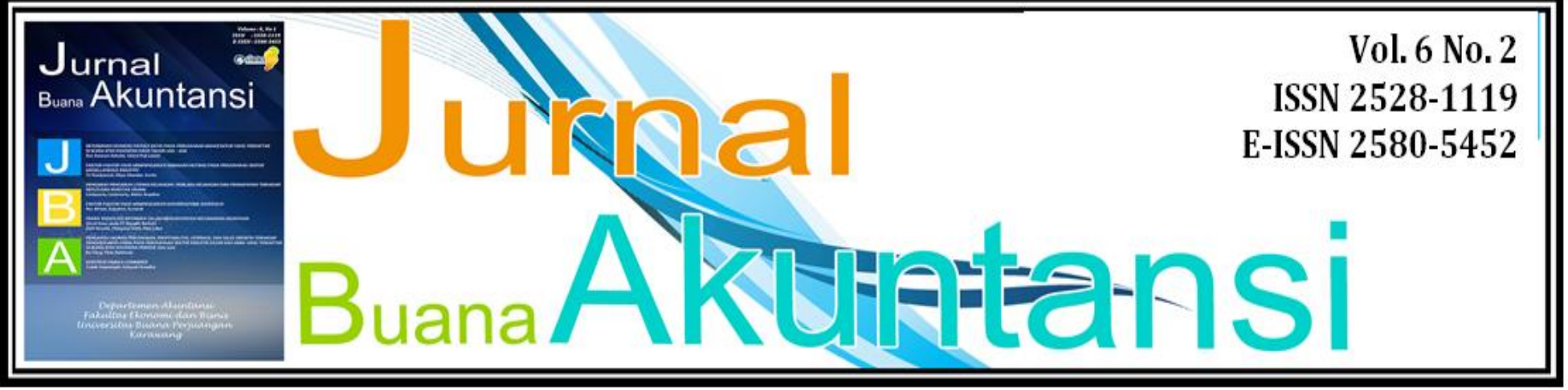

\title{
Evaluasi Sistem Penjualan Tiket Pesawat Dan Kapal Laut Pada Wewe Travel Malang
}

\author{
${ }^{1}$ Glaudiana M Usatnoby, ${ }^{2}$ Nur Ida Iriani, ${ }^{3}$ Ahmad Mukoffi \\ 1,2,3 Universitas Tribhuwana Tunggadewi \\ 1Email : glaudianamakun97@gmail.com
}

\begin{abstract}
Abstrak. Penelitian ini bertujuan untuk mengetahui evaluasi sistem penjualan tiket pesawat dan kapal laut pada wewe travel. Penelitian ini menggunakan penelitian deskriptif kualitatif. Hasil penelitian menunjukkan penerapan sistem akuntansi penjualan tiket berbasis online maupun offline pada wewe travel sudah cukup baik dimana sistem penjualan tiket online terdiri dari penjualan tiket, pencatatan akuntansi, pembuatan bukti transaksi dan verifikasi penjualan menggunakan aplikasi computer berbasis online dan terdapat sistem penjualan offline yang proses transaksi penjualan barang dan jasa secara langsung dimana produsen dan konsumen bertemu dala satu tempat untuk mewujudkan terjadinya proses transaksi jual beli.
\end{abstract}

Kata Kunci : Evaluasi, Sistem Informasi, dan Penjualan.

\section{Pendahuluan}

Dalam dunia bisnis sekarang ini, kebutuhan akan informasi keuangan yang tepat sangatlah diperlukan oleh pihak dalam maupun pihak luar perusahaan. Untuk itu maka disusunlah suatu system akuntansi. Sistem ini dirancang untuk menghasilkan informasi yang berguna bagi pihak dalam maupun pihak luar agar dapat membantu dalam proses pengambilan keputusan.

Menurut Agus Mulyanto (2009 : 12) Sistem akuntansi merupakan jaringan penghubung yang sistematis dalam menyajikan informasi yang berguna dan dapat dipercaya untuk kepentingan pihak pemakai informasi yang berguna dan dapat dipercaya untuk kepentingan pihak pemakai informasi, khususnya manajemen perusahaan. Didalam perusahaan dapat dijumpai ketidaksesuian penerapan sistem akuntansi dalam praktek sehingga terjadi kecurangan-kecurangan dalam perusahaan tersebut. Sistem akuntansi penjualan merupakan faktor yang sangat menentukan keberhasilan suatu perusahaan dalam melakukan penjualan

Penjualan merupakan kegiatan yang dilakukan oleh penjual dalam menjual barang dan jasa dengan harapan akan memperoleh laba dari adanya transaksi-transaksi tersebut dan penjualan dapat diartikan sebagai pengalihan atau pemindahan hak kepemilikan atas barang atau jasa dari pihak penjual ke pembeli (Mulyadi, 2008:202). Siklus penjualan dalam perusahaan meliputi penjualan tunai dan penjualan kredit. Siklus penjualan adalah urutankegiatan sejak diterimanya pesanan dari pelanggan, pengiriman barang, pembuatan (faktur) penagihan, dan 


\section{Buana Akuntansi}

pencatatan penjualan(Krismiaji, 2002:269). Prosedur penjualan melibatkan beberapa bagian dalam perusahaan dengan tujuan agar sistem penjualannya dapatdiawasi dengan baik. Menurut Jones dan Rama (2009:23) prosedur pada penjualan dimulai daripelanggan datang ke perusahaan dan melihat barang yang diinginkan.

Sistem Informasi Akuntansi (SIA) dapat membantu perusahaan dalam menghasilkan suatu informasi yang dapat bermanfaat bagi para penggunanya (Alnajjar, M. I. M. (2017). Dengan terbentuknya sistem informasi akuntansi yang baik maka akan menghasilkan suatu informasi yang relevan, lengkap dan dapat dipercaya. Pentingnya informasi yang berkualitas dapat membantu pihak manajemen dalam proses pengambilan keputusan jangka pendek maupun jangka panjang. Untuk mengatasi atau mengantisipasi terjadinya kerusakan maupun kehilangan data, maka perlu dibuat suatu program atau sistem yang dapat menjaga keamanan data serta dapat menghasilkan suatu laporan yang diinginkan oleh perusahaan, sehingga jika data-data tersebut digunakan sewaktu-waktu maka sangatlah mudah untuk mendapatkannya dan tidak memakan waktu yang lama. Pengendalian intern merupakan suatu hal yang sangat penting bagi manajemen perusahaan guna mengendalikan kegiatan operasi perusahaan dan untuk menjaga asset perusahaan.

Informasi merupakan suatu data yang diorganisasikan dan dapat mendukung ketepatan pengambilan keputusan (Krismiaji, 2010:15). Sedangkan, sistem merupakan pengumpulan sumber daya yang saling terkait untuk mencapai satu tujuan, sehingga Sistem Informasi Akuntansi (SIA) merupakan sebuah sistem yang memproses data keuangan dan data lainnya untuk menghasilkan informasi yang bermanfaat untuk merencanakan, mengendalikan, dan mengoperasikan bisnis untuk memudahkan pihak manajemen dalam mengelolah perusahaan. Sistem Informasi Akuntansi termasuk komponen terpenting dalam setiap jenis bisnis. Keseluruhan transaksi yang mempengaruhi nilai uang semuanya tercatat dalam akuntansi. Sistem Informasi Akuntansi diperlukan oleh manajemen dalam mengevaluasi kinerja perusahaan untuk mencapai efesiensi dalam produktivitas yang lebih tinggi dalam operasi bisnis. Dengan demikian perlu diadakan evaluasi sistem informasi penjualan sehingga sistem informasi yang dihasilkan dapat benar-benar sesuai dengan harapan pimpinan untuk mendukung pengambilan keputusan untuk menentukan langkah apa yang harus dilakukan dalam membuat strategi penjualannya dimasa yang akan datang.

\section{Tinjauan Pustaka \\ Penelitian Terdahulu:}

(Sihombing, D. E. 2010) peneliti ini melakukan penelitian yang berjudul Evaluasi sistem informasi Akuntansi atas penjualan tiket pada PT. Garuda Indonesia (Persero) (Disertasi Doktor, Universitas Mercu Buana).dilakukan melalui pendekatan kualitatif dengan menganalisis sistem informasi akuntansi penjualan tiket dan penerimaan kas menggunakan diagram alir. Hasil penelitian ini menunjukkan bahwa sistem informasi akuntansi penjualan tiket di PT Garuda Indonesia (Persero) sudah baik. Hal ini dikarenakan sistem real time yang digunakan oleh PT Garuda Indonesia (Persero) memberikan banyak keuntungan seperti penyajian informasi ketersediaan kursi dengan akurat dan cepat, sistem online 24 jam yang memungkinkan pelanggan mendapatkan layanan setiap saat.

\subsection{Evaluasi}




\section{Buana Akuntansi}

Evaluasi merupakan salah satu sarana yang penting dalam melakukan kegiatan,baik kegiatan dalam usaha maupun dalampendidikan. Setiap berjalannya kegiatan biasanya evaluasi dilakukan untuk menilai dan mengkaji ulang, guna memperbaiki atau menilai kegiatan tersebut sudah sesuai dengan apa yang diinginkan. Tahap-tahap Evaluasi terdiri dari : apa saja yang dievaluasi, merancang kegiatan evaluasi, pengumpulan data evaluasi, analisis data dan pengolahannya dan pelaporan hasil evaluasi.

\subsection{Sistem Informasi}

Menurut Supriyati (2012: 10), sistem informasi merupakan kumpulan atau unsur dari subsub sistem atau komponen-komponen atau prosedur-prosedur baik fisik maupun nonfisik yang mempunyai fungsi dan prosedur tertentu, saling bekerja sama secara harmonis untuk mencapai suatu tujuan tertentu.

\subsection{Sistem Informasi Akuntansi}

Sistem informasi akuntansi memiliki arti sebuah sistem yang meliputi catatan, formulir, serta laporan dengan susunan tertentu sehingga menghasilkan informasi keuangan yang dibutuhkan perusahaan.Sehingga, manajemen dapat lebih mudah mengontrol kerja sistem yang telah dipakai. Jika dulu catatan akuntansi memakai cara manual. Komponen Sistem Informasi Akuntansi : sumber daya manusia (SDM) yang terlatih yang memahami bisnis proses akuntansi dan keuangan secara umum, misalnya seorang Accounting, prosedur Keuangan dan Akuntansi, formulir Data Keuangan, untuk mencatat seluruh aktifitas keuangan meliputi transaksi kas, persediaan, piutang, aktiva tetap, hutang, penjualan dan biaya, Accounting Software, contohnya: MYOB, zahiraccounting, Oracle Finance, dan Hardware berupa seperangkat komputer yang terhubung dengan jaringan (Networking), dan kelengkapan aksesoris pendukung lainnnya.

\section{Metodologi Penelitian}

\subsection{Desain penelitian}

Penelitian ini menggunakan penelitian deskriptif kualitatif yaitu penelitian yang dilakukan untuk memperoleh gambaran yang lebih jelas dan masalah yang diteliti tentang evaluasi sistem informasi penjulan tiket pesawat dan kapal lau di CV Wewe Travel Malang. penelitian ini bertujuan untuk mendeskripsikan secara tepat tentang sesuatu yang tengah terjadi dan berlangsung. Alasan penulis menggunakan penelitian jenis deskriptif dalam penelitian ini adalah untuk mendeskripsikan, menggambarkan secara sistematis, faktual dan akurat mengenai fakta hubungan dan fenomena.

\subsection{Lokasi peneltian}

Lokasi penelitian pada Usaha Jasa Wewe Travel Merjosari JL. Joyo Raharjo NO.281, Kelurahan Merjosari Kecamatan Lowokwaru Kabupaten Malang.

\subsection{Teknik Analisis Data}

Metode yang akan digunakan dalam penelitian ini adalah metode kualitatif deskriptif, yaitu metode yang sifatnya menguraikan, menggambarkan, membandingkan suatu data dan keadaan serta menerangkan suatu keadaan sedemikian rupa sehingga dapat ditarik kesimpulan. Dalam metode ini tidak menggunakan teknik analisis statistik untuk mengetahui 


\section{Buana Akuntansi}

dan menjawab permasalahan dan tujuan yang akan dicapai, maka data yang banyak diperoleh adalah data melalui wawancara dan observasi.

Analisis data kualitatif dilakukan apabila data empiris yang diperoleh adalah data kualitatif berupa kumpulan berwujud kata-kata dan bukan rangkaian angka serta tidak dapat disusun dalam kategori-kategori/struktur klasifikasi. Data bisa saja dikumpulkan dalam aneka macam cara(observasi, wawancara, intisari dokumen, pita rekaman)dan biasanya diproses terlebih dahulu sebelum siap digunakan(melalui pencatatan, pengetikan, penyuntingan, atau alih-tulis), tetapi analisis kualitatif tetap menggunakan kata-kata yang biasanya disusun ke dalam teks yang diperluas, dan tidak menggunakan perhitungan matematis atau statistika sebagai alat bantu analisis.

Menurut Miles dan Huberman, kegiatan analisis terdiri dari tiga alur kegiatan yang terjadi secara bersamaan, yaitu reduksi data, penyajian data, dan penarikan kesimpulan/verivikasi. Terjadi secara bersamaan berarti reduksi data, penyajian data, dan penarikan kesimpulan/verivikasi sebagai sesuatu yang saling jalin menjalinmerupakan proses siklus dan interaksi padasaat sebelum, selama, dan sesudah pengumpulan data dalam bentuk sejajar yang membangun wawasan umum yang disebut "analisis" (Ulber Silalahi, 2009: 339).

Teknik analisis data yang digunakan dalam penelitian kualitatif mencakup transkip hasil wawancara, reduksi data, analisis, interpretasi datadan triangulasi.Dari hasil analisis data yang kemudian dapat ditarik kesimpulan.berikut ini adalah teknik analisis data yang digunakan oleh peneliti:

\section{Reduksi Data}

Reduksi data bukanlah suatu hal yang terpisah dari analisis. Reduksi data diartikan sebagai proses pemilihan, pemusatan perhatian pada penyederhanaan, pengabstraksian, dan transformasi data kasar yang muncul dari catatan-catatan tertulis di lapangan. Kegiatan reduksi data berlangsung terus-menerus, terutama selama proyek yang berorientasi kualitatif berlangsung atau selama pengumpulan data.Selama pengumpulan data berlangsung, terjadi tahapan reduksi, yaitu membuat ringkasan, mengkode, menelusuri tema, membuat gugusgugus, membuat partisi, dan menulis memo.

Reduksi data merupakan suatu bentuk analisis yang menajamkan, menggolongkan, mengarahkan, membuang yang tidak perlu, dan mengorganisasi data sedemikian rupa sehingga kesimpulan-kesimpulan akhirnya dapat ditarik dan diverivikasi. Reduksi data atau proses transformasi ini berlanjut terus sesudah penelitian lapangan, sampai laporan akhir lengkap tersusun.Jadi dalam penelitian kualitatif dapat disederhanakan dan ditransformasikan dalam aneka macam cara: melalui seleksi ketat, melalui ringkasan atau uraian sigkat, menggolongkan dalam suatu pola yang lebih luas, dan sebagainya.

\section{Triangulasi}

Selain menggunakan reduksi data peneliti juga menggunakan teknik Triangulasi sebagai teknik untuk mengecek keabsahan data.Dimana dalam pengertiannya triangulasi adalah teknik pemeriksaan keabsahan data yang memanfaatkan sesuatu yang lain dalam membandingkan hasil wawancara terhadap objek penelitian (Moloeng, 2004:330).

Triangulasi dapat dilakukan dengan menggunakan teknik yang berbeda (Nasution, 2003:115) yaitu wawancara, observasi dan dokumen.Triangulasi ini selain digunakan untuk 


\section{Buana Akuntansi}

mengecek kebenaran data juga dilakukan untuk memperkaya data. Menurut Nasution, selain itu triangulasi juga dapat berguna untuk menyelidiki validitas tafsiran peneliti terhadap data, karena itu triangulasi bersifat reflektif. Denzin (dalam Moloeng, 2004), membedakan empat macam triangulasi diantaranya dengan memanfaatkan penggunaan sumber, metode, penyidik dan teori.Pada penelitian ini, dari keempat macam triangulasi tersebut, peneliti hanya menggunakan teknik pemeriksaan dengan memanfaatkan sumber.

Triangulasi dengan sumber artinya membandingkan dan mengecek balik derajat kepercayaan suatu informasi yang diperoleh melalui waktu dan alat yang berbeda dalam penelitian kualitatif (Patton,1987:331). Adapun untuk mencapai kepercayaan itu, maka ditempuh langkah sebagai berikut :

1) Membandingkan data hasil pengamatan dengan data hasil wawancara

2) Membandingkan apa yang dikatakan orang di depan umum dengan apa yang dikatakan secara pribadi.

3) Membandingkan apa yang dikatakan orang-orang tentang situasi penelitian dengan apa yang dikatakannya sepanjang waktu.

4) Membandingkan keadaan dan perspektif seseorang dengan berbagai pendapat dan pandangan masyarakat dari berbagai kelas.

5) Membandingkan hasil wawancara dengan isi suatu dokumen yang berkaitan.

\section{Menarik Kesimpulan}

Kegiatan analisis ketiga adalah menarik kesimpulan dan verivikasi.Ketika kegiatan pengumpullan data dilakukan, seorang penganalisis kualitatif mulai mencari arti benda-benda, mencatat keteraturan, pola-pola, penjelasan, konfigurasi-konfigurasi yang mungkin, alur sebab akibat, dan proposisi. Kesimpulan yang mula-mulanya belum jelas akan meningkat menjadi lebih terperinci. Kesimpulan-kesimpulan "final" akan muncul bergantung pada besarnya kumpulan-kumpulan catatan lapangan, pengkodeannya, penyimpanan, dan metode pencarian ulang yang digunakan, kecakapan peneliti, dan tuntutan pemberi dana, tetapi sering kali kesimpulan itu telah sering dirumuskan sebelumnya sejak awal. 


\section{Buana Akuntansi}

\section{Analisis dan Pembahasan}

SISTEM FLOWCHART PENJUALAN TIKET PADA WEWE TRAVEL.

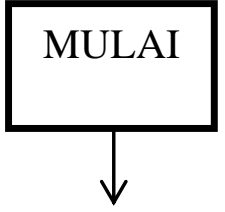

Konsumen mendatangi tempat Usaha Jasa Wewe Travel untuk memilih tujuan keberangkatan.

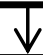

Setelah sampai di tempat usaha jasa tersebut, konumen langsung memilih jenis penerbangan yang ada.

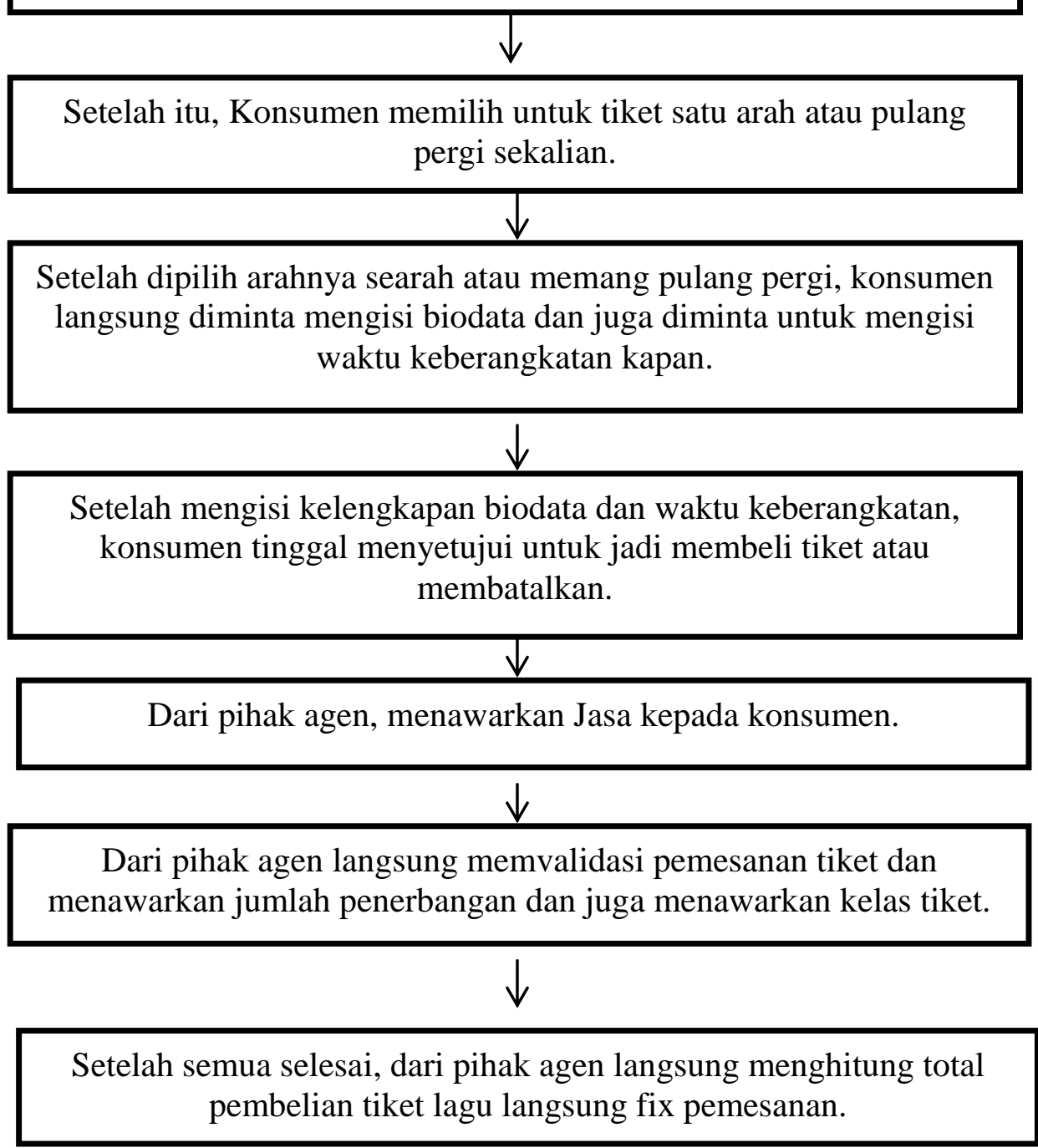




\section{Buana Akuntansi}

* Deskripsi alur penjualan tiket.

- Konsumen menandatangani agen tiket untuk pemesanan tiket pesawat dan kapal laut.

- Agen menawarkan jasa kepada konsumen dan konsumen memilih tujuan penerbangan.

- Konsumen dipersilahkan untuk memilih jenis penerbangan yang di inginkan, apakah ingin memesan tiket untuk pulang dan pergi, atau memilih tiket untuk sekali jalan.

- Konsumen mengisi waktu penerbangan yang diinginkan serta identitas lengkap dari konsumen yang akan melakukan penerbangan.

- Agen memastikan lagi apakah identitas dan jam penerbangan yang diinginkan oleh konsumen benar/salah.

- Saat konsumen sudah fix dengan penerbangan yang di inginkan, pembayaran dilakukan dan agen tiket memberikan voucher yang harus ditukarkan menjadi tiket penerbangan di bandara dan pelabuhan

Untuk mengetahui suatu sistem penjualan di Wewe Travel, disini saya sebagai peneliti menggunakan sistem Flowchart sistem yang di mana flowchart sistem ini merupakan bagan yang menunjukkan alur kerja atau apa yang sedang dikerjakan. Dengan menggunakan sistem flowchart sistem ini, kita bisa mengetahui sistem penjualan yang digunakan di Wewe Travel sudah sesuai atau belum.Dengan adanya deskripsi bagan alir penjualan tiket yang sesuai dengan sistem flowchart sistem ini adalah bahwa siste penjualan yang diterapkan di Wewe Travel sudah sesuai maka tidak perlu lagi usulan sistem. 
* Flowchart Sistem Akuntansi Penjualan Tunai pada Wewe Travel Malang. Fungsi yang terkait dalam melaksanakan transaksi retur penjualan adalah :

1. Bagian Penjualan

\section{Bagian Order Penjualan}

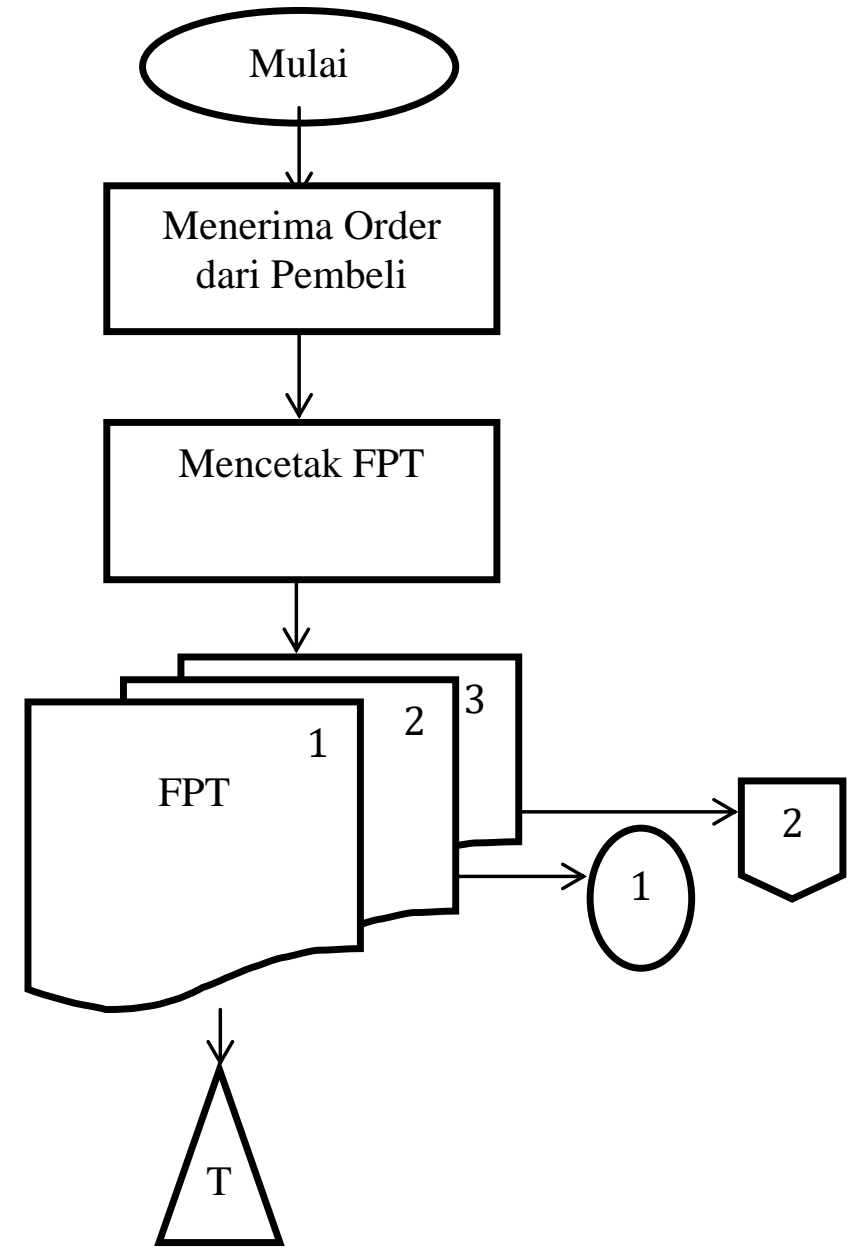


FPT : Faktur Penjualan Tunai.

2. Bagian Kas

\section{Bagian Kas}

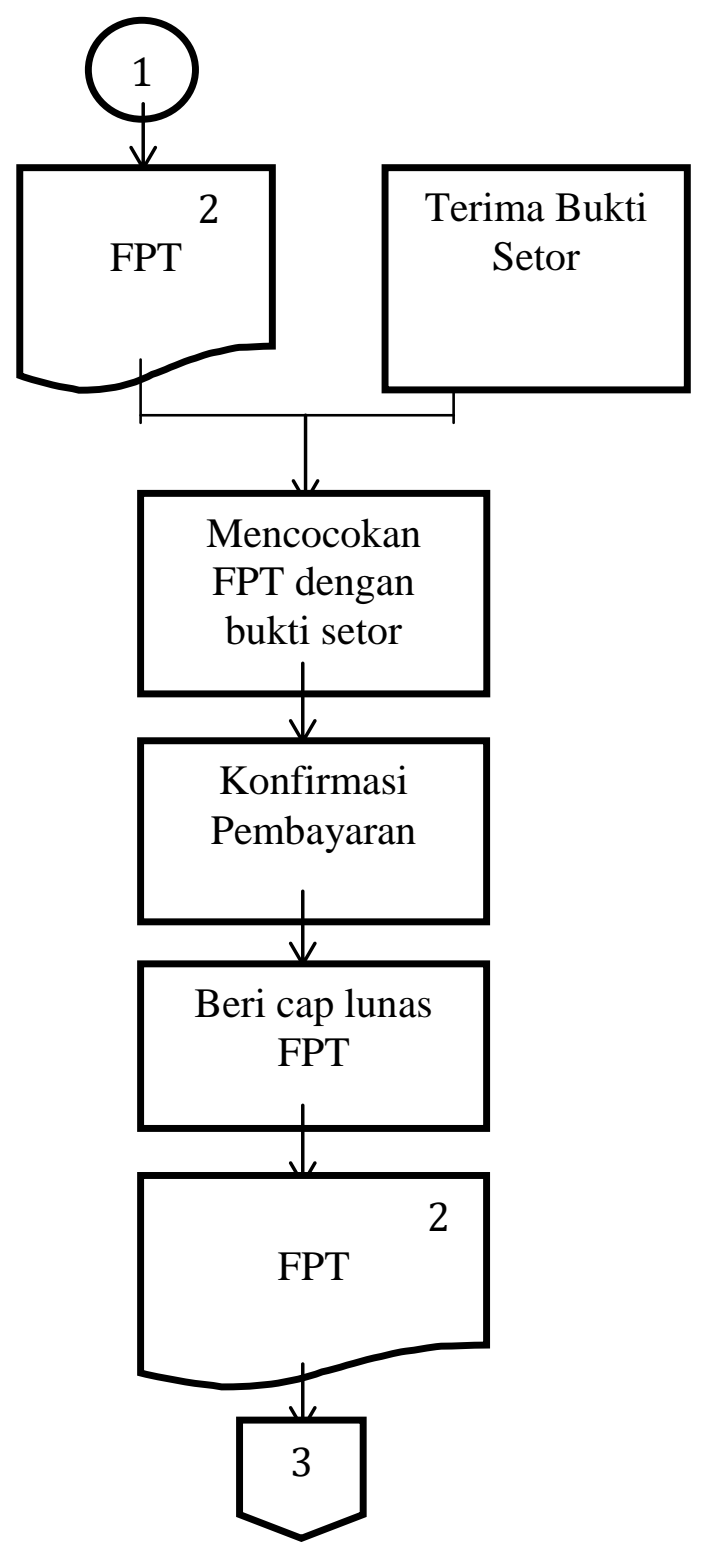




\section{Buana Akuntansi}

3. Bagian Akuntansi

Bagian Akuntansi

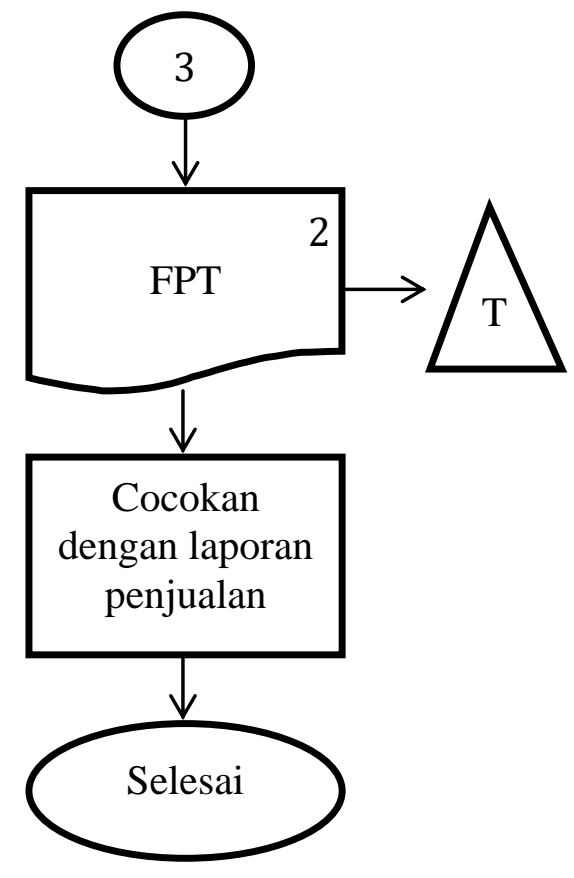

Berikut adalah penjelasan flowchart sistem akuntansi penjualan tunai :

a Bagian Penjualan

1)Menerima order pembelian dari pelanggan.

2)Mencetak faktur penjualan tunai yang sudah otomatis dibuat oleh sistem rangkap.

Untuk pelanggan FPT akan otomatis ditampilkan dihalaman profil dalam web.

3)FPT 1 diarsip berdasarkan tanggal oleh bagian penjualan.

4)FPT 2 diserahkan kepada bagian kas untuk dicocokan apakah sudah melakukan pembayaran dan FPT 3 untuk menyiapkan pesanan.

b Bagian Kas

1)Menerima FPT 2 dari bagian penjualan

2)Menerima pembayaran dari pembeli

3)Mencocokan bukti transfer dengan FPT 2 yang diserahkan dari bagian penjualan

4)Apabila sudah cocok maka diberi cap lunas dan langsung diserahkan untuk mengetahui bahwa barang yang sudah dipesan sudah dibayar lunas

c Bagian Akuntansi

1)Menerima FPT 2

2)FPT dicocokan dengan laporan penjualan

3)FPT 2 langsung diarsipkan sesuai tanggal

* Sistem Pengendalian Intern pada Wewe Travel

Sistem pengendalian intern yang diterapkan pada Wewe Travel masih belum berjalan dengan baik. Berikut adalah sistem pengendalian dari wewe travel : 


\section{Buana Akuntansi}

\section{a Organisasi}

Penerapan pengendalian intern pada organisasi belum diterapkan dengan baik dikarenakan masih adanya perangkapan fungsi pada bagian akuntansi dan kasir, selain itu juga bagian produksi.

b Sistem Otorisasi

Sistem otorisasi belum dijalankan pada wewe travel, maka sistem pengendalian intern pada sistem otorisasi belum berjalan sesuai dengan teori.

c Praktik yang Sehat

Pada wewe travel masih belum diterapkannya praktik yang baik dimana tidak dilakukannya percocokan fisik dengan catatannya dan tidak adanya rotasi jabatan.

d Karyawan

Karyawan yang bekerja pada wewe travel beberapa sudah sesuai mutu dengan tanggung jawabnya. Namun untuk hal pencatatan karena masih bersifat seadanya sehingga mutunya masih rendah.

Perancangan Sistem Akuntansi Penjualan Tunai

\begin{tabular}{|l|l|l|}
\hline Jenis Analisis & Sistem Lama & Sistem Baru \\
\hline (Performance) & $\begin{array}{l}\text { Pembuatan pesanan } \\
\text { pembelian dilakukan secara } \\
\text { manual sehingga terbatas } \\
\text { oleh jam berja karyawan } \\
\text { saja dalam pelayanan } \\
\text { penjualan. }\end{array}$ & $\begin{array}{l}\text { Mampu mengatasi dalam } \\
\text { kecepatan perhitungan pesanan } \\
\text { dan laporan yang dihasilkan } \\
\text { sesuai dengan jumlah pesanan } \\
\text { dan tagihan serta pelayanan } 24 \\
\text { jam. }\end{array}$ \\
\hline $\begin{array}{l}\text { Informasi } \\
\text { (Information) }\end{array}$ & $\begin{array}{l}\text { Masih sederhana karena } \\
\text { masih kurangnya informasi } \\
\text { yang dihasilkan dari sistem } \\
\text { lama tersebut dan } \\
\text { penyimpanannya belum } \\
\text { tertata dengan baik. }\end{array}$ & $\begin{array}{l}\text { Dapat memberikan informasi } \\
\text { yang lengkap dan tersimpan } \\
\text { dengan baik. }\end{array}$ \\
\hline $\begin{array}{l}\text { Ekonomi } \\
\text { (Economy) }\end{array}$ & $\begin{array}{l}\text { Penjualan yang ada hanya } \\
\text { dilakukan ketika adanya } \\
\text { pemeran dan titip jual di } \\
\text { tokko saja. Selain itu tida } \\
\text { ada pengiklanan produk. }\end{array}$ & $\begin{array}{l}\text { Dapat memberikan perbaikan } \\
\text { dalam penjualan dan } \\
\text { pemasaran produk. }\end{array}$ \\
\hline $\begin{array}{l}\text { Pengendalian } \\
\text { (Control) }\end{array}$ & $\begin{array}{l}\text { Sistem pengendalian yang } \\
\text { berjalan dapat } \\
\text { menimbulkan manipulasi } \\
\text { karena belum berjalannya } \\
\text { otorisasi. }\end{array}$ & $\begin{array}{l}\text { Penyimpanan data transaksi } \\
\text { pada sistem baru akan } \\
\text { dilakukan secara otomatis, } \\
\text { sistem otorisasi diterapkan } \\
\text { pada semua fungsi. }\end{array}$ \\
\hline $\begin{array}{l}\text { Efisiensi } \\
\text { (Eficiency) }\end{array}$ & $\begin{array}{l}\text { mengandalkan penjualan } \\
\text { secara tatap muka saja } \\
\text { sehingga jika tidak ada } \\
\text { transaksi penjualan tidak }\end{array}$ & $\begin{array}{l}\text { Mampu menggantikan } \\
\text { pemborosan dalam sumber } \\
\text { daya manusia yang ada serta } \\
\text { menjadi media promosi untuk } \\
\text { meningkatkan penjualan. }\end{array}$ \\
\hline
\end{tabular}




\section{Buana Akuntansi}

\begin{tabular}{|l|l|l|}
\hline & bekerja. & \\
\hline $\begin{array}{l}\text { Pelayanan } \\
\text { (Service) }\end{array}$ & $\begin{array}{l}\text { Hanya bisa melakukan } \\
\text { transaksi pada jam kerja } \\
\text { saja dan pembeli harus } \\
\text { datang langsung ke toko } \\
\text { atau saat pameran saja. }\end{array}$ & $\begin{array}{l}\text { Mampu melayani pembeli 24 } \\
\text { jam tanpa berhenti dan pembeli } \\
\text { dapat melakukan ransaksi } \\
\text { dimana saja. }\end{array}$ \\
\hline
\end{tabular}

\section{Kesimpulan, Keterbatasan, dan Saran}

\subsection{Kesimpulan}

Berdasarkan hasil penelitian yang didapatkan pada Wewe Travel Malang, maka di ambil kesimpulan sebagai berikut :

Penerapan sistem akuntansi penjualan tiket berbasis online maupun offline pada Wewe travel sudah cukup baik sistem akuntansi penjualan tiket online terdiri dari penjualan tiket, pencatatan akuntansi, pembuatan bukti transaksi dan verifikasi penjualan menggunakan aplikasi komputer berbasis online. Dan Sistem pengendalian internal terhadap sistem akuntansi penjualan tiket berbasis online telah memenuhi komponen pengendalian internal perusahaan namun dari hasil pengamatan yang dilakukan masih ditemukan Sistem informasi penjualan Wewe travel, bisa terjadi perubahan sesuai dengan kondisi apa yang dapat terjadi dan secara negatif mempengaruhi kemampuan entitas terhadap informasi kepada pelanggan. Sehingga selain mengelola meringkas dan melaporkan data keuangan yang konsisten dalam laporan keuangan. Resiko terhadap terjadi revant atau pengembalian tiket sangat berpengaruh terhadap hasil penjualan kedepannya, oleh karena itu Untuk mengatasi resiko tersebut pihak Wewe travel menyiapkan sistem informasi yang baru.

\subsection{Keterbatasan}

Berdasarkan pada pengalaman langsung peneliti dalam proses penelitian ada beberapa keterbatasan yang dialami dan dapat menjadi beberapa faktor yang dapat untuk lebih diperhatikan bagi peneliti-peneliti yang akan datang dalam lebih menyempurnakan penelitiannya karena penelitian ini sendiri memiliki kekurangan yang perlu terus diperbarui dalam penelitian-penelitian ke depannya.

Beberapa keterbatasan yang ada ialah : Peneliti hanya meneliti satu lokasi agen travel yakni Wewe Travel Malang yang dimana belum bisa menggambarkan keadaan yang sesungguhnya.

\subsection{Saran}

Diharapkan pihak perusahaan untuk melakukan evaluasi atas sistem otorisasi dan prosedur pencatatan dalam pelaksanaan distribusi penjualan yang telah dilakukan oleh perusahaan, yaitu dengan melakukan pembagian tugas dan wewenang yang memadai sehingga dapat mendukung internal check di dalam unit organisasi dan menyebabkan data akuntansi yang dihasilkan dapat dipercaya atas kebenarannya.

Perusahaan diharapkan untuk lebih memperhatikan atas usaha-usaha yang dilakukan dalam rangka untuk membentuk karyawan yang benar-benar memiliki kemampuan serta kompetensi yang tinggi dalam usaha pencapaian tujuan perusahaan. Langkah nyata yang dapat dilakukan oleh perusahaan adalah dengan mengikutsertakan para karyawan dalam 
kegiatan pelatihan, terutama yang dilakukan di luar perusahaan, yang bertujuan dalam usaha meningkatkan kemampuan dalam bekerja di perusahaan. Melalui usaha tersebut, para karyawan akan memiliki kemampuan yang mampu bersaing dengan perusahaan yang lain, sehingga para karyawan dapat bekerja secara maksimal di perusahaan.

Terakhir, pihak perusahaan diharapkan untuk melakukan evaluasi atas sistem dan prosedur pengendalian secara berkala, dengan harapan pihak perusahaan dapat dengan segera menetapkan kebijakan agar tidak terjadi adanya penyimpangan yang dapat meragukan perusahaan.

\section{Daftar Pustaka}

Adypato. (2010). Materi Pengoptimalan Sumber Daya Universitas Mataram. Diambil dalam http:/ /www.google.com/url?q =https:/ /adypato.files.wordpress.co m/2010/11/.pptx Agoes,Soekrisno , 2004, AUDITING, Penerbit Fakultas Ekonomi Universitas Indonesia, Jakarta. Agus Mulyanto. 2009. Sistem Informasi Konsep dan Aplikasi. Yogyakarta. Pustaka Pelajar.

Azhar Susanto. 2008 Sistem Informasi Akuntansi.

Bandung: Lingga. Jaya. Any Krisnawati, Suhadak dan Topowijono, 2013. Analisis Sistem Informasi Akuntansi Penjualan Dan Penerimaan Kas (Studi Pada Penjualan Speedy Pt. Telekomunikasi Indonesia, Tbk Kandatel Malang).

Baridwan, Z. 2003. Sistem Akuntansi: Penyusunan Prosedur dan Metode. Cetakan Ketiga. Yogyakarta: Penerbit BPFE.

Bayu, R. C. (2016). Evaluasi Sistem Pengendalian Internal pada Sistem Penjualan dan Penerimaan Kas" (Studi Kasus pada PT Indomarine) (Doctoral dissertation, University of Muhammadiyah Malang).

Bodnar, G.H., dan William, S.H. 2005. Sistem Informasi Akuntansi. Edisi Indonesia. Alih bahasa: Amir Abadi Yusuf. Jakarta: Penerbit Salemba Empat.

Firmansyah, A., \& Merlina, N. (2020). PREDIKSI POLA PENJUALAN TIKET KAPAL PT. PELNI CABANG MAKASSAR MENGGUNAKAN METODE ALGORITMA APRIORI. JITK (Jurnal Ilmu Pengetahuan Dan Teknologi Komputer), 5(2), 183-190.

Hankorindo Surya Abado Sidoarjo. E-Journal Akuntansi" EQUITY", 3(3).

http:/ /eprints.undip.ac.id/40650/3/BAB_III.pdf

http://etheses.uin-malang.ac.id/2150/7/11520062_Bab_3.pdf

http://library.binus.ac.id/eColls/eThesisdoc/Bab2/2007-2-00300-KA-Bab\%202.pdf

http://seputarpengertian.blogspot.com/2016/10/pengertian-evaluasi-dan-tahapannya.html https://accurate.id/akuntansi/sistem-informasi-akuntansi/ https://dinus.ac.id/repository/docs/ajar/JURNAL_SI_PENJUALAN_TIKET.pdf https://elib.unikom.ac.id/files/disk1/626/jbptunikompp-gdl-antonfajri-31261-10-unikom_1i.pdf

https://kamus.tokopedia.com/p/pengendalian-intern/ https://kamus.tokopedia.com/p/pengendalian-intern/ https://saintif.com/evaluasi-adalah/\# https://sasteralupus.wordpress.com/2009/11/04/pengendalian-intern/ https://www.google.com/search?client=firefox-b$\mathrm{d} \& \mathrm{q}=$ pengertian+analisis + deskriptif + kualitatif

61| P a g e 


\section{Buana Akuntansi}

https:/ / www.google.com/search?safe=strict\&biw=1366\&bih=654\&ei=Z2OiX8aaAca5rQH9zJD $4 \mathrm{Ag \& q}=$ pengertian+penjualan+online + dan + offline\&oq=pengertian + penjualan + online\& gs_lcp=

https://www.kembar.pro/2015/11/pengertian-dan-fungsi-utama-sistem-informasiakuntansi.html

https:/ / zahiraccounting.com/id/blog/tujuan-dan-manfaat-sistem-informasi-akuntansi/

Junesti, H. Pemanfaatan Sistem Informasi Manajemen Terhadap Pengambilan Keputusan Oleh Kepala Sekolah.

Jurnal Administrasi Bisnis (JAB)Vol. 1 No. 1. Aisiyah Kusuma Wardani, 2013. Penerapan Sistem Informasi Akuntansi Penjualan PT. Nasmoco Bengawan Motor Solo Slamet Riyadi.

Krismiaji, 2002, Sistem Informasi Akuntansi, Unit Penerbit dan Percetakan AMP YKPN, Yogyakarta.

Mulyadi. 2008. Sistem Akuntansi. Jakarta: Salemba Empat.

Peniarsih, P., \& Andriandi, A. (2018). ANALISIS DETERMINAN SISTEM INFORMASI ETICKETING (PENDEKATAN EXTENDED THEORY OF PLANNED BEHAVIOUR). Journal of Information System, Applied, Management, Accounting and Research, 2(3), $40-52$.

Perusahaan Keramik Dinding dalam rangka meningkatkan Produktivitas Perusahaan pada PT. Wijaya, R. D. (2013). Evaluasi Implementasi Sistem Informasi Reservasi Online (Studi Pada Vip Enterprise Malang). Jurnal Administrasi Bisnis, 4(1).

Purwanto, T. D., \& Wijaya, A. (2017). Evaluasi Aplikasi Exploid Wifi Di Tingkat Availability Dan Vulnerability. Simetris: Jurnal Teknik Mesin, Elektro dan Ilmu Komputer, 8(2), 801806.

Rama, Dasaratha V. dan Frederick L. Jones 2009. Sistem Informasi Akuntansi. Salemba Empat. Jakarta.

Sihombing, D. E. (2010). Evaluasi sistem informasi Akuntansi atas penjualan tiket pada PT. Garuda Indonesia (Persero) (Doctoral dissertation, Universitas Mercu Buana).

Wulan, G. C. (2017). Evaluasi Sistem Informasi Akuntansi atas Sistem Penjualan pada Susanto, B. Evaluasi sistem informasi akuntansi penjualan tiket BPU Rosalia Indah (studi kasus pada BPU Rosalia Indah). 